\title{
The hydrological model and formula for determining the hypothetical flood wave volume in non-gauged basins
}

\author{
Wiesław Gądek, Marek Bodziony \\ Institute of Water Engineering and Water Management, Cracow University of Technology, Warszawska Street 24, \\ 31-155 Kraków, Poland, e-mail: wgadek@iigw.pl
}

\begin{abstract}
Determination of theoretical flood waves, commonly known as hypothetical waves, is still a difficult problem to be solved. Most frequently hydrological modelling is used for this purpose. However, there are no methods for verifying the obtained calculation results. The assumption applied, that daily precipitation with a defined height difference probability triggers off a theoretical wave with the same probability of excess, was verified in four upland basins whose river mouths are located within Kraków metropolitan area. It was proved that in order to meet the assumption made, it is necessary for the precipitation duration, with defined height difference probability, to last 48 hours, because for daily precipitation the volume of calculated theoretical flood wave is too small. During the calculations, the hydrological model was used, as was the formula for flood wave volume determination for the area of Upper Vistula River, as developed by the main author of the publication. The relative error of the reduced volumes in relation to the volumes calculated with the Kraków method for theoretical flood waves, was lower than $30 \%$ in any case. Therefore, it can be acknowledged that the suggested method may be used for determining theoretical flood waves in any cross-section for the non-gauged catchment with a surface not exceeding $400 \mathrm{~km}^{2}$.
\end{abstract}

Keywords: Theoretical flood wave, Hypothetical flood wave, Unified Unit Hydrograph UHG SCS, non-gauged catchment, reduced volume, the Kraków method

Submitted 14 November 2014, revised 28 January 2015, accepted 9 April 2015

\section{Introduction}

The application of hypothetical waves for designing hydrotechnical facilities, the control and management of those facilities and for demarcating threatened areas by means of estimating spatial risk (Büchele et al. 2006; Ernst et al. 2010) and appraisal of losses in life and property (Jonkman et al. 2008), are currently the main procedures in contemporarily understood water management (Linsley et al. 1975; Pilgrim 2001), as are questions related to low-water periods and drought (Tokarczyk, Szalińska 2013). Considering the possibilities at our disposal, we may state that there is no problem with determining the course during theoretical flows in gauged sections i.e. those where we have sufficient information on the course of real flood waves. The problem appears when we want to apply similar solutions in non-gauged basins. On the flow hydrograph that should be treated as reliable during hydrotechnical designing, there is a problem regarding the lack of proper tools for determining its course in time.

In the gauged sections, a number of methods are significant; when we consider the method for determining the course of these flood waves, we can divide things into two groups: those determined on the basis of a single biggest flood wave, and those for several of the biggest mono- modal flood waves. For the most part, the methods based on a single maximal flood wave are used:

- Reitz-Kreps Method (Kiciński 1965; Ciepielowski, Dąbkowski 2006; Gądek, Środula 2014),

- Strupczewski Method (1964) - two equations,

- McEnroe Method (1992),

- Hydroprojekt.

The Warsaw University of Technology method and The Cracow University of Technology method are based on averaging courses from flow hydrographs. In The Warsaw University of Technology method (Gądek 2012) 6 flood waves are required, and in The Cracow University of Technology method 8 are required (Gądek 2010, 2012a, 2012b, 2014a).

Determination of theoretical flood waves in nongauged basins is conducted with the use of mathematical hydrological modelling (Gądek 2012; Wałęga 2013). It is assumed that the probability of the maximal registered daily precipitation is the same as the probability of run-off from the basin. Is this approach justified? The following questions arise: why use the registered daily precipitation and not the daily precipitation which, according to German standards is $14 \%$ higher than daily precipitation (correction Weiss) (Stachý, Fal 1986); and why use the daily precipitation and not precipitation with a different dura- 
tion? An indisputable fact is that the registered daily precipitation is the basis for conducting all types of analyses, both formerly and currently (Wypych et al. 2014; Wójcik et al. 2014; Szalińska et al. 2014).

The aim of this publication is to verify whether taking the registered daily precipitation with a defined height difference probability for calculations is a correct assumption. Perhaps one should use maximal precipitations with a defined height difference probability and with a longer duration. In the estimation made, a method was applied which supported the method used while determining the course of hypothetical flood waves in the nongauged basins with the application of the empirical formula, as developed in the Institute of Water Engineering and Water Management, Cracow University of Technology, which defined the flood wave volume for specified flow in culmination, and the course in time was established by means of a UHG SCS hydrograph. The developed formula was designated for the whole area of the Upper Vistula River up to the Zawichost section (Gądek 2014b). It may be used for basins with areas up to $400 \mathrm{~km}^{2}$. The HECHMS 3.4 was applied as the hydrological model used for determining the theoretical hydrographs. This model was developed by the American Army Engineering Corps (HEC-HMS 2009), and as the verifying basins four upland basins whose mouths to the Vistula river are located within Kraków metropolitan area were selected.

\section{Description of method}

While analysing the results obtained through the Cracow University of Technology method (Gądek 2010, $2012 b$ ), the distinct relation between the maximal flow reduced value and hypothetical wave reduced volume (Fig. 1) was noted. The reduced flow value is understood as the flow decreased by the va-lue of maximal flow with a defined height difference probability of $Q_{\mathrm{p}}=50 \%$.

The reduced volume is understood as the flood wave volume above the base flow (of cut-off) $Q_{\mathrm{p}=50 \%}$. This dependence was considered as essential and work was under-

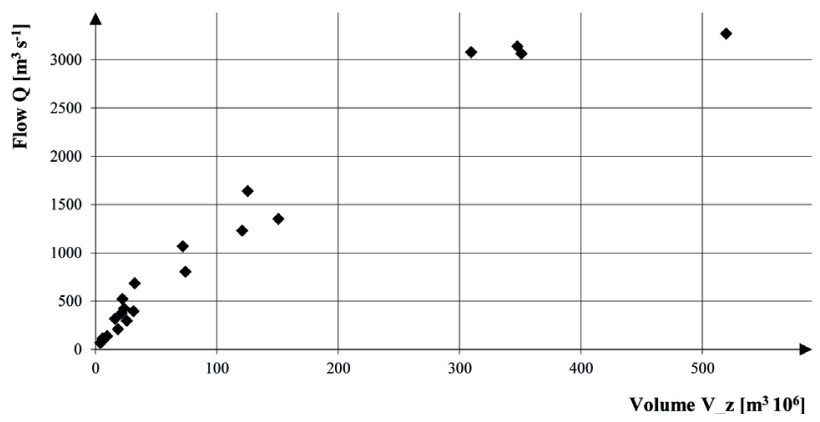

Fig. 1. Dependence of maximal flow reduced value on the flood wave reduced volume for Dunajec basin Source: own study taken in order to develop a formula enabling the definition of the relation between these values. The developed formula uses the results obtained through the Cracow University of Technology method (Gądek 2010, 2012a), and it was presented during the Second National Congress of Hydrologists (Gądek 2014b).

\section{Description of determined formula}

The dependence course of the coefficient $\mathrm{wspV}$ on the basin surface was designated on the basis of the conducted analyses and series of test. The coefficient wspV converts the reduced flow height into the hypothetical reduced wave volume, and it is established according to the rules accepted for the Kraków method (Gądek 2010, 2012a). In Fig. 2, the course of the coefficient change dependent on the basin surface value is presented graphically.

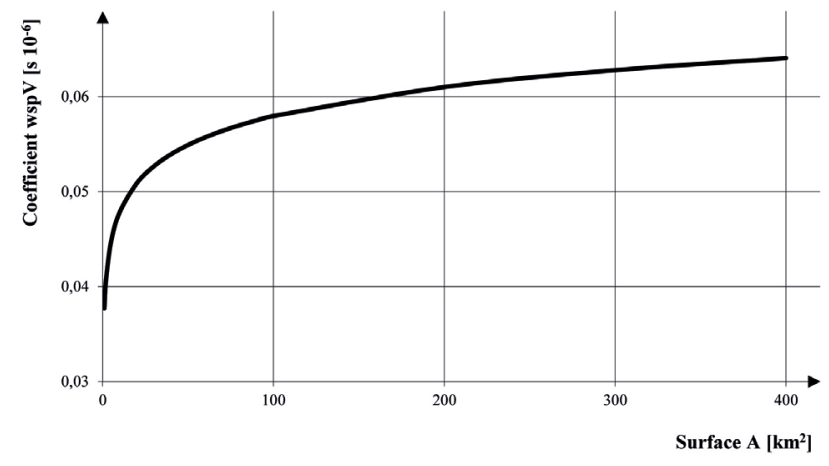

Fig. 2. Dependence of the coefficient changing the reduced flow volume on the hypothetical wave reduced volume wspV for developed empirical formula. Source: own study

The proposed formula is presented with the equation:

$$
\mathrm{wspV}=0,0044( \pm 14 \%) \ln (A)+0,0377( \pm 9 \%)
$$

where: wspV - the coefficient connecting the wave reduced volume with the maximal reduced flow in culmination $\left[10^{-6} \mathrm{~s}\right] ; A$ - basin surface from 10 to $400 \mathrm{~km}^{2}\left[\mathrm{~km}^{2}\right]$.

The formula was developed based on the selected 48 hypothetical waves with the Kraków method. The calculation process was conducted in basins from $22.8 \mathrm{~km}^{2}$ to $362 \mathrm{~km}^{2}$. These basins are located in different areas of the Upper Vistula inflow region. They are mountainous, upland and lowland basins. The only criterion while choosing a basin was area and its location in the area of examined inflow region i.e. the Upper Vistula river, as well as a factor that was equally important in many cases - the data enabling the determination of the hypothetical wave in the water gauged section according to the Kraków method. Hereafter the proposed formula is called the "formula on volume". 


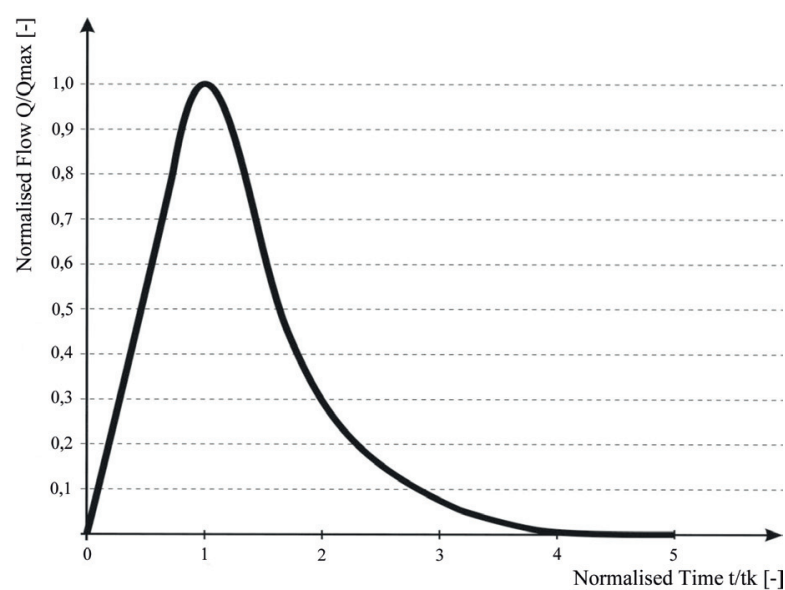

Fig. 3. Unified course of unit hydrograph UHG SCS according to the Hydrologic Research Laboratory \& National Operational Hydrologic Remote Sensing Center (source: own study)

The course of hypothetical flood wave with determined flow volume was accepted according to the rules made for typical wave shape for small basins by the American Soil Conservation Service (US SCS). The course of a unified wave is presented in Fig. 3 and the hydrograph coordinates are given in Table 1 (according to the Hydrologic Research Laboratory \& National Operational Hydrologic Remote Sensing Center - NOHRSC).

Table 1. Unified course coordinates for unit flood wave UHG SCS (according to NOHRSC) in the non-dimensional system

\begin{tabular}{|c|c|c|c|c|c|}
\hline$t / t_{k}$ & $Q / Q_{\max }$ & $t / t_{k}$ & $Q / Q_{\max }$ & $t / t_{k}$ & $Q / Q_{\max }$ \\
\hline 0,0 & 0,000 & 1,1 & 0,990 & 2,4 & 0,147 \\
\hline 0,1 & 0,030 & 1,2 & 0,930 & 2,6 & 0,107 \\
\hline 0,2 & 0,100 & 1,3 & 0,860 & 2,8 & 0,077 \\
\hline 0,3 & 0,190 & 1,4 & 0,780 & 3,0 & 0,055 \\
\hline 0,4 & 0,310 & 1,5 & 0,680 & 3,2 & 0,040 \\
\hline 0,5 & 0,470 & 1,6 & 0,560 & 3,4 & 0,029 \\
\hline 0,6 & 0,660 & 1,7 & 0,460 & 3,6 & 0,021 \\
\hline 0,7 & 0,820 & 1,8 & 0,390 & 3,8 & 0,015 \\
\hline 0,8 & 0,930 & 1,9 & 0,330 & 4,0 & 0,011 \\
\hline 0,9 & 0,990 & 2,0 & 0,280 & 4,5 & 0,005 \\
\hline 1,0 & 1,000 & 2,2 & 0,207 & 5,0 & 0,000 \\
\hline
\end{tabular}

\section{Description of hydrological model applied}

The hydrological model built based on the HEC-HMS software developed by the American Army Engineering Corps was used for determining the course of hypothetical flood waves. The rainfall hyetograph was accepted as homogenous for the total surface of the basin and the course was described as the density cumulative distribution function beta:

$$
f(\mathrm{x})=\frac{\mathrm{x}^{\alpha^{-1}}(1-\mathrm{x})^{\beta-1}}{B(\alpha, \beta)}
$$

where: $\alpha, \beta-$ the shape coefficients, $\alpha>0$ and $\beta>0 ; 0 \leq \mathrm{x}$ $\leq t ; B$ - beta function; $t$ - duration of rainfall.

The height of rainfall was taken as maximal precipitation with the height difference probability $p=1 \%$ and defined duration of $24,32,40,48$ and 72 hours. The precipitation course was effectively calculated while using the NRCS-CN method, considering the influence of land development, type of soil, character of vegetation and the state of basin moisture content on the culmination flow value.

\section{Description of test methodology}

The flow hydrographs while using the hydrological model for maximal daily precipitation with the height difference probability $p=1 \%$ were determined for four selected upland river basins: Prądnik, Dłubnia, Podłężanka and Kościelnicki stream. The obtained hydrographs were compared with the hypothetical wave course determined while using the developed formula on volume. The analysed sections were located in the upper, middle and bottom part of the basin. For each basin four sections were designated, though, because of its length, for the Dłubnia river there were five sections.

It was found that in all considered sections the wave volume calculated based on $24 \mathrm{~h}$ of precipitation with the hydrological model is smaller than the one calculated with the "formula on volume". While not making any changes in the general rules accepted in the hydrological modelling, i.e. parameters for the NRCS-CN (Ignar 1988) and the rainfall distribution obtained through the density cumulative distribution function beta, the rainfall distributions with the same height difference probability $p=1 \%$

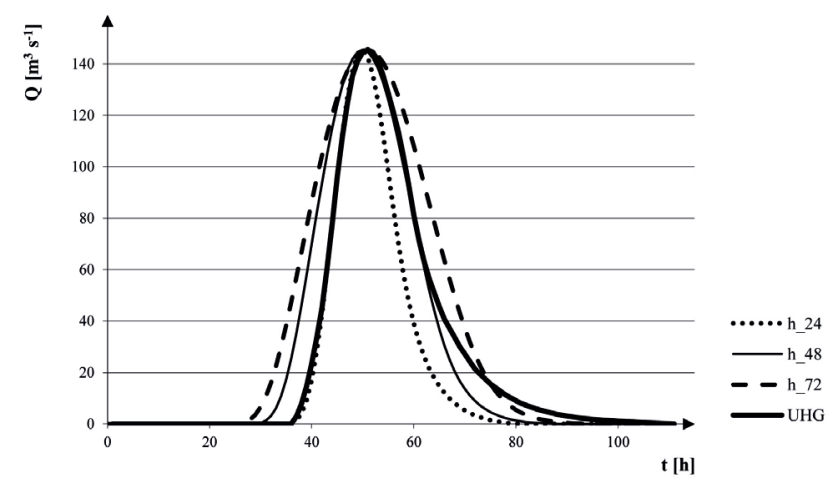

Fig. 4. Hypothetical hydrographs calculated using the hydrological model and precipitation duration 24 hours (h_24), 48 hours (h_48) and 72 hours (h_72) and the hydrograph determined with the developed formula on rainfall while using UHG SCS hydrograph (UHG) - source: own study 
with the defined duration were used i.e.: $32,40,48$ and 72 hours. The rainfall height for those defined time periods was calculated according to the rules given by (Stachý, Fal 1986). In Fig. 4 the example hydrographs calculated with the hydrological model for the precipitation duration 24, 48 and 72 hours and the flood wave course according to the developed formula (1) with the accepted course UHG SCS are presented.

\section{Test results}

Based on the quoted example it can be stated that the closest in shape, course and value of the wave volume is the hydrograph calculated for precipitation with duration 48 hours. In table 2 the flood wave volumes for particular calculated sections at the defined time period of the precipitation with the defined height difference probability $p=1 \%$, and the volume calculated with the "formula on volume", are presented.

Based on the values quoted in Table 2, a calculation was made for the precipitation time which should be applied at the rainfall distribution so that the flood wave volume calculated using the hydrological model can be equal to the volume calculated with the "formula on volume". The results are shown in Fig. 5.

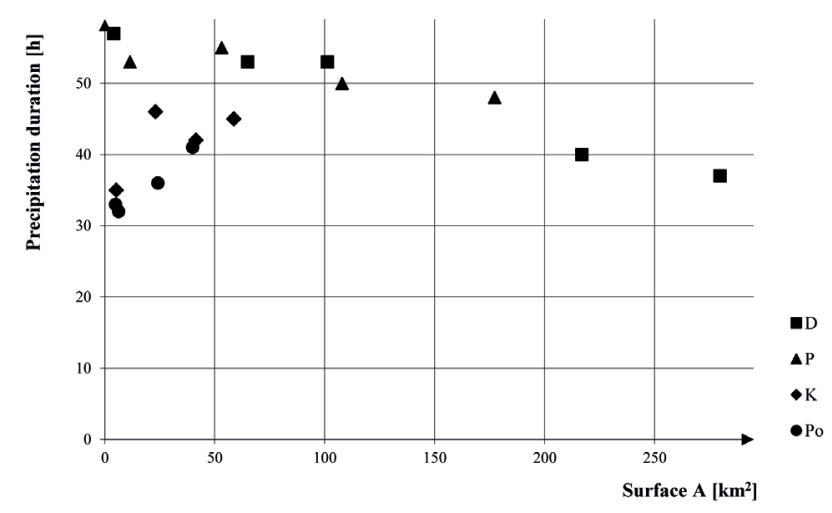

Fig. 5. Required rainfall duration with the height difference probability $\mathrm{p}=1 \%$ for particular surfaces of the river basins (D Dłubnia, P - Prądnik, K - Kościelnicki stream, Po - Podłężanka) so that the volume calculated with the hydrological model is equal to the volume calculated with the "formula on volume" source: own study

For the accepted calculation sections the duration of rainfall is from 32 to 55 hours i.e. it is longer than the presently accepted 24 hours. It is impossible to state explicitly, based on the obtained results, what duration of rainfall should be taken. The arithmetic average value for all calculation results is 44 hours. For this rainfall duration value the hypothetical wave volume was calculated with the hydrological model and the results were compared

Table 2. Hydrograph volume values for precipitation with the height difference probability $p=$ $1 \%$ and duration $24,32,40,48$ and 72 hours and the volume designated while using the "formula on volume"

\begin{tabular}{|c|c|c|c|c|c|c|c|}
\hline \multirow[b]{2}{*}{ River } & \multirow{2}{*}{$\begin{array}{c}\text { Basin surface } \\
{\left[\mathrm{km}^{2}\right]}\end{array}$} & \multicolumn{6}{|c|}{ Flood wave volume for the precipitation duration $\left[10^{6} \mathrm{~m}^{3}\right]$} \\
\hline & & $\begin{array}{c}24 \\
{[\mathrm{~h}]}\end{array}$ & $\begin{array}{c}32 \\
{[\mathrm{~h}]}\end{array}$ & $\begin{array}{c}40 \\
{[\mathrm{~h}]}\end{array}$ & $\begin{array}{l}48 \\
{[\mathrm{~h}]}\end{array}$ & $\begin{array}{c}72 \\
{[\mathrm{~h}]}\end{array}$ & Formula \\
\hline \multirow{5}{*}{ Dłubnia } & 4,05 & 0,143 & 0,170 & 0,197 & 0,218 & 0,276 & 0,242 \\
\hline & 64,9 & 2,259 & 2,698 & 3,129 & 3,475 & 4,395 & 3,705 \\
\hline & 101,2 & 3,484 & 4,165 & 4,836 & 5,372 & 6,800 & 5,655 \\
\hline & 216,9 & 7,080 & 8,501 & 9,905 & 11,030 & 13,955 & 9,882 \\
\hline & 279,8 & 9,446 & 11,311 & 13,149 & 14,621 & 18,351 & 12,334 \\
\hline \multirow{4}{*}{ Prądnik } & 11,53 & 0,457 & 0,533 & 0,614 & 0,687 & 0,858 & 0,721 \\
\hline & 53,2 & 1,756 & 2,078 & 2,422 & 2,738 & 3,476 & 2,957 \\
\hline & 107,9 & 3,422 & 4,064 & 4,748 & 5,377 & 6,850 & 5,433 \\
\hline & 177,9 & 5,842 & 6,917 & 8,062 & 9,113 & 11,551 & 9,074 \\
\hline \multirow{4}{*}{ Kościelnicki } & 5,21 & 0,199 & 0,240 & 0,275 & 0,307 & 0,385 & 0,249 \\
\hline & 23,1 & 0,880 & 1,064 & 1,218 & 1,359 & 1,705 & 1,307 \\
\hline & 41,5 & 1,548 & 1,876 & 2,150 & 2,401 & 3,018 & 2,194 \\
\hline & 58,7 & 2,313 & 2,790 & 3,187 & 3,549 & 4,439 & 3,395 \\
\hline \multirow{4}{*}{ Podłężanka } & 4,9 & 0,326 & 0,373 & 0,414 & 0,452 & 0,546 & 0,375 \\
\hline & 6,3 & 0,422 & 0,483 & 0,536 & 0,584 & 0,705 & 0,481 \\
\hline & 24,2 & 1,566 & 1,796 & 1,996 & 2,179 & 2,636 & 1,905 \\
\hline & 39,9 & 2,485 & 2,854 & 3,177 & 3,473 & 4,214 & 3,195 \\
\hline
\end{tabular}

Source: own study 
with the calculations from the "formula on volume"; the results pertaining to the relative error for the precipitation duration 24, 44 and $48 \mathrm{~h}$ are given in Table 3. The error of the hypothetical flood wave volume in relation to the volume calculated with the formula was calculated:

$$
\text { Error }=\frac{V_{\text {hip }}-V_{\text {form }}}{V_{\text {form }}} 100 \%
$$

where: Error - relative error for calculated volume of the hypothetical flood wave [\%]; $V_{\text {hip }}$ - hypothetical flood wave volume $\left[\mathrm{m}^{3}\right] ; V_{\text {form }}$ - flood wave volume calculated with the "formula on volume" $\left[\mathrm{m}^{3}\right]$.

\section{Summary and conclusions}

The calculations conducted for the four upland basins indicate unequivocally that while using the hydrological models of rainfall-runoff type for the hypothetical wave calculations one must make allowances for longer durations of rainfall. In all the considered sections the theoretical flood wave volume was significantly smaller than the volume calculated with the "formula on volume", and this pattern is designated on the basis of the real data on the courses of waves in 48 basins in the area of the Up- per Vistula River. The suggested duration of rainfall with defined height difference probability should be 44 hours. However, due to the fact that the rainfall height had to be calculated while using the formulas proposed by Stachý (Stachý, Fal 1986) or auxiliary tables, it seems legitimate to establish the time for 48 hours for upland basins. For basins with a different nature, similar calculations are necessary in order to establish such a time.

In most cases, the suggested time of $48 \mathrm{~h}$ for rainfall with defined height difference probability $=1 \%$ translates into the flood wave volumes which in comparison with the "formula on volume" are above $20 \%$ of the relative error. In only three cases was this error greater - this related to very small basins with a surface area of up to $10 \mathrm{~km}^{2}$. To sum up, when for the rainfall with defined height difference probability and duration of $48 \mathrm{~h}$ are introduced to the calculation, a much better determined hypothetical flood wave is acquired. These flood waves are characterised with more reliable volume when compared to the flood waves calculated using rainfall with 24-hour duration. The maximal flow in the culmination does not change, but the shape changes i.e. the course in time, and this is of crucial importance when designing and demarcating danger zones.

Table 3. Relative error calculated for the hypothetical flood wave volume determined while using the hydrological model and precipitation duration 24, 44 and 48 hours in relation to the volume calculated with the "formula on volume"

\begin{tabular}{|c|c|c|c|c|}
\hline \multirow[b]{2}{*}{ River } & \multirow[b]{2}{*}{$\begin{array}{c}\text { Basin surface } \\
{\left[\mathrm{km}^{2}\right]}\end{array}$} & \multicolumn{3}{|c|}{ Relative error calculated for rainfall with duration [\%] } \\
\hline & & $\begin{array}{l}24 \\
{[\mathrm{~h}]}\end{array}$ & $\begin{array}{l}44 \\
{[\mathrm{~h}]}\end{array}$ & $\begin{array}{l}48 \\
{[\mathrm{~h}]}\end{array}$ \\
\hline \multirow{5}{*}{ Dłubnia } & 4,05 & $-41,1$ & $-15,0$ & $-10,4$ \\
\hline & 64,9 & $-39,0$ & $-11,5$ & $-6,6$ \\
\hline & 101,2 & $-38,4$ & $-10,3$ & $-5,4$ \\
\hline & 216,9 & $-28,4$ & 5,0 & 10,8 \\
\hline & 279,8 & $-23,4$ & 11,6 & 17,6 \\
\hline \multirow{4}{*}{ Prądnik } & 11,53 & $-36,7$ & $-10,3$ & $-5,6$ \\
\hline & 53,2 & $-40,6$ & $-13,4$ & $-8,3$ \\
\hline & 107,9 & $-37,0$ & $-7,4$ & $-2,1$ \\
\hline & 177,9 & $-35,6$ & $-6,0$ & $-0,7$ \\
\hline \multirow{4}{*}{ Kościelnicki } & 5,21 & $-20,1$ & 16,2 & 22,3 \\
\hline & 23,1 & $-32,7$ & $-2,0$ & 3,3 \\
\hline & 41,5 & $-29,4$ & 3,0 & 8,5 \\
\hline & 58,7 & $-31,9$ & $-1,3$ & 3,7 \\
\hline \multirow{4}{*}{ Podłężanka } & 4,9 & $-13,1$ & 15,4 & 20,5 \\
\hline & 6,3 & $-12,4$ & 16,3 & 20,5 \\
\hline & 24,2 & $-17,8$ & 9,7 & 13,9 \\
\hline & 39,9 & $-22,2$ & 4,2 & 8,6 \\
\hline
\end{tabular}


Hence, there is only one conclusion; instead of 24-hour precipitation and the defined height difference probability, 48-hour precipitation should be used for the hydrological modelling. For such precipitation, the determined theoretical flood waves in the non-gauged basins will in their courses and volume be close to the waves developed for the gauged basin. In addition, it is necessary to introduce flow value control with defined height difference probability in the calculation nodes through the application of a statistical method as well as indirect methods (Banasik et al. 2012).

Bibliography

Banasik K., Byczkowski A., Hejduk L., Gładecki J., 2012, Estimation of probable flood flows in small catchments with the use of direct (statistical) and indirect methods (in Polish), Woda-Środowisko-Obszary Wiejskie, 12 (3), 17-26

Büchele B., Kreibich H., Kron A., Thieken A., IhriInger J., Oberle P., Merz B., Nestmann F., 2006, Flood-risk mapping: contributions towards an enhanced assessment of extreme events and associated risks, Natural Hazards and Earth System Sciences, 6, 485-503, DOI: 10.5194/nhess-6-485-2006

Ciepielowski A., Dąbkowski S., 2006, Methods for calculating maximum discharges in small catchments (in Polish), Projprzem-EKO, Bydgoszcz, Poland, $311 \mathrm{pp}$.

Ernst J., Dewals B.J, Detrembleur S., Archambeau P., 2010, Micro-scale flood risk analysis based on detailed 2D hydraulic modelling and high resolution geographic data Natural hazards, Natural Hazards, 55 (2). 181-209, DOI: 10.1007/ s11069-010-9520-y

Gądek W., 2010, Hypothetical flood hydrographs with peak value of given exceedance probability (in Polish) [in:] Hydrologia w inżynierii i gospodarce wodnej, vol. 1, Monografie KGW-PAN 68, B. Więzik (eds.), KGW-PAN, Stowarzyszenie Hydrologów Polskich, Warszawa, 177-186

Gądek W., 2012a, Determination of design hydrographs in gauged catchments using the Warsaw University of Technology method and Cracow University of Technology method - Part I -description of the methods (in Polish), Czasopismo Techniczne, 2-Ś (23), 95-104

Gądek W. 2012b, Determination of design hydrographs in gauged catchments using the Warsaw University of Technology method and Cracow University of Technology method - Part II -evaluation of the methods (in Polish), Czasopismo Techniczne, 2-Ś (23), 105-126

Gądek W., 2014a, Assessment of limnigraph data usefulness for determining the hypothetical flood waves with the Cracow method, Journal of Water and Land Development, 21 (1), 7178, DOI: 10.2478/jwld-2014-0016,
Gądek W. 2014b, Theoretical flood waves for non-gauged catchments (in Polish), [in:] Hydrologia w inżynierii i gospodarce wodnej, vol. 1., Monografie KGW-PAN XX, K. Banasik, L. Hajduk, E. Kaznowska, KGW-PAN, Stowarzyszenie Hydrologów Polskich, 139-150

Gądek W., Banach W., Fiołka I., 2012, Application of a Geomorphological model for the determination of design floods (in Polish), Czasopismo Techniczne, 1-Ś (4), 59-67

Gądek W., Środula A., 2014, Evaluation of design flood parameters determined with the Reitz and Kreps method in gauged basins (in Polish), Woda-Środowisko-Obszary Wiejskie, 14 (3), 29-47

HEC-HMS, 2009, Hydrologic Modelling System HEC-HMS. User's Manual, US Army Corps of Engineers, Hydrologic Engineering Center, 442 pp., last version available at http://www.hec.usace.army.mil/software/hec-hms/documentation/HEC-HMS_Users_Manual_4.0.pdf (data access 30.04.2015)

Ignar S., 1988, SCS method and its application for determining the effective precipitation (in Polish), Przegląd Geofizyczny, 33 (4), 451-455

Jonkman S.N., Vrijling J.K., Vrouwenvelder A.C.W.M., 2008, Methods for the estimation of loss of life due to floods: a literature review and a proposal for a new method, Natural Hazards, 46 (3), 353-389, DOI: 10.1007/s11069-008-9227-5 Kiciński T., 1965, Construction of a probable flood hydrograph (in Polish), Zeszyty Naukowe SGGW. Melioracje Rolne, 6, 49-71

Linsley Jr. R.K., Kohler M.A., Paulhus J.L.H., 1975, Hydrology for engineers, McGraw-Hill, Incorporated, New York, 482 pp.

McEnroe B.M. 1992, Sizing stormwater detention reservoirs to reduce peak flows, [in:] Hydraulic engineering: saving a threatened resource - in search of solutions, Conference Proceeding Paper, Reston, VA, 719-724

NOHRSC, Unit Hydrograph (UHG), Technical Manual, 19 pp.

Pilgrim D.H. (eds.), 2001, Australian rainfall and runoff. A guide to flood estimation, vol. 1, Institution of Engineers, Australia Stachý J., Fal B., 1986, The principles for probable maximal flows calculation (in Polish), Prace Instytutu Badania Dróg i Mostów, 3-4, 91-147

Strupczewski W., 1964, Equation of flood crest (in Polish), Wiadomości Służby Hydrologicznej i Meteorologicznej, 2 (57), 35-58

Szalińska W., Otop I., Tokarczyk T., 2014, Precipitation extremes during flooding in the Odra River Basin in May-June 2010, Meteorology Hydrology and Water Management, 2 (1), 13-20

Tokarczyk T., Szalińska W., 2013, The operational drought hazard assessment scheme - performance and preliminary results, Archives of Environmental Protection, 39 (3), 61-77 
Wałęga A., 2013, Application of HEC-HMS programme for the reconstruction of a flood event in an uncontrolled basin, Journal of Water and Land Development, 18 (9), 13-20, DOI: 10.2478/jwld-2013-0002

Wójcik R., Pilarski M., Miętus M., 2014, Statistical downscaling of probability density function of daily precipitation on the Polish coast, Meteorology Hydrology and Water Management, 2 (1), 27-36
Wypych A., Ustrnul Z., Henek E., 2014, Meteorological Hazards - Visualization System for National Protection Against Extreme Hazards for Poland, Meteorology Hydrology and Water Management, 2 (1), 37-42 